\title{
Positive outcomes between herbivore diversity and tree survival: Responses to management intensity in a Patagonian forest
}

\author{
M.E. Nacif ${ }^{a, b}, *$ T. Kitzberger ${ }^{c}$, L.A. Garibaldi ${ }^{\mathrm{a}, \mathrm{b}}$ \\ ${ }^{a}$ Universidad Nacional de Río Negro, Instituto de Investigaciones en Recursos Naturales, Agroecología y Desarrollo Rural, San Carlos de Bariloche, Río Negro, Argentina \\ ${ }^{\mathrm{b}}$ Consejo Nacional de investigaciones Científicas y Técnicas, Instituto de Investigaciones en Recursos Naturales, Agroecología y Desarrollo Rural, San Carlos de Bariloche, \\ Río Negro, Argentina \\ ${ }^{\mathrm{c}}$ CONICET, INIBIOMA-Universidad Nacional del Comahue, Quintral 1250, 8400 Bariloche, Río Negro, Argentina
}

\section{A R T I C L E I N F O}

\section{Keywords:}

Cutting and harvesting in strips

Arthropod guilds

Commercial plantation

Nothofagus obliqua

\begin{abstract}
A B S T R A C T
Sustainable forest management aims to both enhance biodiversity and tree productivity. However, trade-offs may exist between these objectives, e.g. arthropod diversity and associated arthropod herbivory can reduce tree growth and survival. Tree productivity and biodiversity may also show non-linear responses to management intensity, making applied recommendations even more challenging. We studied the effects of harvesting intensity for firewood extraction in a northern Patagonian forest (Argentina) on leaf damage diversity (as a proxy of arthropod folivore diversity), leaf damage frequency, growth and survival of planted trees of Nothofagus obliqua for timber purpose. We randomly applied four levels of harvesting intensity $(0,30,50$, and $70 \%$ of basal area removal) in experimental plots and we followed the responses on the focal planted tree species during two growing seasons. After harvesting, air temperature and photosynthetic active radiation increased, while relative humidity decreased, with harvesting intensity. Leaf damage diversity and frequency showed non-linear responses to harvesting intensity, both achieving its highest values at intermediate harvesting intensities ( $30 \%$ and $50 \%$ of basal area removal). Such responses were consistent for contrasting feeding guilds, using different diversity indices, and during the two study growing seasons. Interestingly, leaf damage diversity and frequency were positively and strongly correlated across the plots. Despite great leaf damage frequency (around $45 \%$ of the leaves were damaged), plant survival was also highest at intermediate harvesting intensities during the two years. Planted trees also grew more at intermediate harvesting intensities during the second year, but increased linearly with harvesting intensity during the first year. Hence, at intermediate harvesting intensity, no trade-off was observed between arthropod biodiversity and planted tree sapling survival and growth. In northern Patagonia, trees may face less competition for light and soil resources at intermediate harvesting intensities, while at high harvesting intensities water stress typical of dry Patagonian summers could reduce tree survival. Such benefits were not offset by the greater leaf damage (associated with enhanced damage diversity) observed at intermediate harvesting intensities. Therefore, intermediate levels of management intensity can provide the double service of increasing arthropod diversity and maximizing tree survival and growth, especially during the most critical establishment period.
\end{abstract}

\section{Introduction}

Forests have multiple functions that deliver various combinations of goods and services (FAO, 2016). Sustainable forest management focuses on optimizing both long-term productivity and biodiversity conservation (Bravo-Oviedo et al., 2018). However, trade-offs between a target and non-target ecosystem services or functions may arise when applying a given management practice or sets of practices. For example, harvesting for firewood extraction and fire hazard reduction in forests could generate changes in the microenvironment (e.g. temperature, light availability, humidity), affecting plant and animal communities as well as interactions among them (Soler et al., 2016, Chaudhary et al., 2016). Although these responses are expected to be modulated by the intensity of the intervention, thresholds that combine management productivity with forest sustainability and conservation are little explored. Harvesting in strips or systematic thinning is a type of forest management that can potentially combine some dimensions of sustainable management (such as implantation of economically important

\footnotetext{
* Corresponding author.

E-mail address: mnacif@unrn.edu.ar (M.E. Nacif).
} 
tree species), biodiversity conservation and firewood extraction (Soler et al., 2016; Bravo-Oviedo et al., 2018). Yet, it is unclear at which harvesting intensity this intervention could maximize biodiversity and timber production of both planted trees and woody species within the matrix.

Sustainable forest management must guarantee biodiversity conservation, even when is classified functionally as "undesirable", such as arthropod herbivores. Arthropod herbivory is one of the key ecosystem process that influences different ecosystem services (e.g. by enhancing forest biodiversity or affecting timber production, among others, Maguire et al., 2015). Herbivore species make up a quarter of the existing organisms (Stam et al., 2014), consuming between 5\% and 18\% of the plant biomass (Turcotte et al., 2014) and contributing to nutrient cycling (Gong \& Zhang, 2014). Despite the importance of herbivores as ecosystem engineers (Stam et al., 2014; Gong \& Zhang, 2014), there is still limited information on the relationship between forest management practices and functional diversity of herbivores (Soler et al., 2016). It is even less clear how changes in herbivore diversity might affect herbivory rates in such conditions.

It is uncertain how forest disturbance intensity can shape arthropod herbivory rates, directly or indirectly (Underwood et al., 2014; Gossner et al., 2014; Klapwijk et al., 2016, Appendix 1). On the one hand, with increasing management intensity (e.g. harvesting), herbivory could decrease due to the reduction in plant density and foliage connectivity (resource concentration and spillover hypothesis, Silva et al., 2016; Maguire et al., 2015). On the other hand, herbivory could increase with management intensity in the planted individuals due to a higher rate of encounter of these plants (apparency hypothesis, Castagneyrol et al., 2013) or because of the typical higher average temperature of harvested plots (higher temperature in temperate environments improves the performance of arthropods, optimal temperature hypothesis, Cornellisen, 2011). Alternatively, intermediate management intensity would favour herbivory either because planted individuals survive and grow better (plant vigour hypothesis, Cornelissen et al., 2008) or because there is greater plant diversity (intermediate disturbance hypothesis, Schowalter, 2012; Liebhold et al., 2018; Muiruri et al., 2019). In contrast, it is also predicted that herbivory would be more intense at either extreme of management intensity because planted individuals are highly affected by shade (low management intensity) or high radiation levels (high management intensity), and herbivores would prefer stressed plants (plant stress hypothesis, White, 2009). It is clear that harvesting modifies biotic and abiotic conditions for plants and arthropods (and resulting arthropod herbivory rates) in a complex way, and the potential outcome remains elusive. Hence, this context-dependency requires and justifies experimental approaches which can help to disentangle and identify appropriate management levels.

Forest management practices could also be combined to maximize profit and long-term sustainability, but its success would also depend on appropriate management levels. A large body of research has focused on forest regeneration processes following natural disturbances (e.g. the role of forest gaps, Veblen et al., 2006; Gönc et al., 2015; Pafundi et al., 2016), but only a few studies have applied this knowledge to the performance of native tree plantations under different harvesting intensities (Soto et al., 2015; Donoso \& Promis, 2015). Native tree plantations have many benefits such as increased timber production and value, increased diversity, and scenic value (Bravo-Oviedo et al., 2018; Liu et al., 2018). As regards environmental conditions, if the frequency of intervention increases (e.g. high harvesting intensity, opening large understory areas), it is expected that at the forest floor temperature and evapotranspiration would rise, relative humidity decrease, and wind speed dramatically change (Chaudhary et al., 2016). Such scenario would limit the success of tree plantations, as plants under low canopy cover are usually limited by enhanced water demands driven by higher radiation, while under high canopy cover plants are limited by lower radiation (Bauhus et al., 2010; Liu et al., 2018). Furthermore, varying harvesting intensities can also affect planted tree growth and survival through biotic changes such as arthropod herbivory rates (Stam et al., 2014; Gong \& Zhang, 2014). In summary, the success of management practice (e.g. performance of planted trees) will be contingent on the intensity of other management practices (e.g. harvesting) by altering the balance of both abiotic and biotic factors.

This type of mixed forests are one of the most diverse ecosystems of northwestern Patagonia (Speziale \& Ezcurra, 2011), and historically they have been heavily used for firewood extraction, cattle breeding and exotic tree plantation (Rusch et al., 2017). In the last decades, a renewed interest has emerged to sustainably manage these ecosystems (Rusch et al., 2017), but adequate levels of management intensity for this ecosystem has been poorly assessed. These mixed forests also serve as a successional transition towards tall Nothofagus or Austrocedrus dominated forests (Veblen et al. 2006), but they have rarely been used as natural nurseries for native tree plantations. Trees of the genus Nothofagus, such as $N$. dombeyi (Mirb) Oerst. (coihue), N. pumilio (Poepp et Endl.) Krasser. (lenga), N. alpina (Poepp et Endl.) Oerst. (raulí) and N. obliqua (Mirb) Oerst. (roble pellín) are potential candidates for native species plantations (Donoso \& Promis, 2015). Among them, N. obliqua native to northern Patagonia has been identified as one of the species with better forestry aptitude due to its rapid growth and high timber quality, even more than non-natives ones (Donoso \& Promis, 2015). At the same time, it is one of the most consumed species within the Nothofagus genus by various arthropod herbivores. This is probably driven by its high leaf palatability associated with high nitrogen content (Bauerle et al., 1997; Donoso Zegers 2013). The objective of this study is to assess how harvesting intensities within a mixed forest, influence arthropod herbivore diversity, arthropod herbivory rates, and growth and survival of planted $N$. obliqua saplings. Specifically, our research questions addressed whether there are optimal harvesting intensities for conserve herbivore diversity and tree performance, and to understand if higher herbivore diversity is associated with greater leaf damage.

\section{Materials and methods}

\subsection{Study site and harvesting experiments}

This study was carried out during 2013, and 2014 on an experimental site encompassing high-density mixed forests, near El Foyel (Río Negro Province, Argentina, $41^{\circ} 38^{\prime} 48.44^{\prime \prime}$ S, $71^{\circ} 29^{\prime} 59.06^{\prime \prime} \mathrm{W}$ ), located at an altitude of $790 \mathrm{~m}$ a.s.l. Woody species that conform the mixed forest are Nothofagus antarctica (Nothofagaceae), Diostea juncea (Rhamnaceae), Schinus patagonicus (Anacardiaceae), Lomatia hirsuta (Proteaceae), Embothrium coccineum (Proteaceae), among others (Reque, 2007). Average basal area is $46.7 \mathrm{~m}^{2} \mathrm{ha}^{-1}$, the average basal diameter of trees is $6.1 \mathrm{~cm}$, and the average dominant height is $4.4 \mathrm{~m}$. The weather is cold-temperate with a rainfall season during autumn and winter, reaching approximately $1100 \mathrm{~mm}$ annually. Average annual temperatures range from $8{ }^{\circ} \mathrm{C}$ to $10{ }^{\circ} \mathrm{C}$, with a maximum of $17{ }^{\circ} \mathrm{C}$ and minimum of $2.5{ }^{\circ} \mathrm{C}$, annual relative humidity is around $75 \%$, and annual dew temperature is $3.9^{\circ} \mathrm{C}$. Frosts are present about 80 days per year, mainly during June-August. The soil belongs to the group of Hapludands, with dark, little sandy and abundant roots.

Within this continuous mixed forest, in May 2013, we applied four increasing levels of harvesting intensities in four plots (31.5 $\mathrm{m} \times 45.0 \mathrm{~m}$, Appendix 2). The plots were aligned (east-west) and separated around $30 \mathrm{~m}$ between them. We quantified harvesting intensities as the percentage of removed basal area (30\%, 50\% and 70\%), harvesting was done following strips of different widths according to the harvesting intensities, across whole plot. In the plot with $30 \%$ intensity, the six strips had a width of $1.5 \mathrm{~m}$ (leaving a space of $3.0 \mathrm{~m}$ for intact vegetation on the sides), in the plot with $50 \%$ intensity the six strips were $2.5 \mathrm{~m}$ wide (remaining vegetation $2.0 \mathrm{~m}$ wide), and finally in the plot with $70 \%$ intensity the six strips had $3.5 \mathrm{~m}$ width (remnant vegetation $1.0 \mathrm{~m}$ wide). In the control plot, vegetation was left uncut ( $0 \%$ of removal). Within the strips, all trees and bushes were cut with 
chainsaws and clearing saws at ground level, leaving them the possibility to regrown as these are mostly sprouting species. Young trees of Nothofagus obliqua were planted for sustainable production where harvesting in strips was done, proposing here a short-term study. Nothofagus obliqua does not grow naturally in the latitude of the experimental site but includes their potential planting area and genetic zone (Barbero et al., 2011; Azpilicueta et al., 2016). In one strip of each plot, 30 saplings of $N$. obliqua (3-4 years old and $0.5-0.8 \mathrm{~m}$ height) were planted (optimal plant age to improve the establishment after plantation); in this experiment was use one strip of every plot. The saplings were obtained from three different geographic provenances from Neuquén province (Estación INTA-Pilo Lil, Estación INTA-Yuco Alto, Estación INTA-Quila Quina), where ten from each provenance (so that the comparisons between treatments were not confused by particular differences between origins). The trees were planted in the middle of the harvested strips, and the position of the strip in the plot was randomized. The plants were separated by $1.5 \mathrm{~m}$ in the line, so the plantation density was 1269 plants ha $^{-1}$ approximately, these densities are expected to be compatible with the development of wild forest species (Azpilicueta et al., 2010).

In order to measure arthropod herbivory, we randomly selected twelve saplings per plot (four saplings from each origin, in total 48 plants). In each individual, we sampled small marked branches from intermediate heights of the plant and arthropod herbivory was recorded in 18 leaves per branch. We measured arthropod herbivory for two years on four dates during the spring (October and December) and summer (February and April), following the same trees and branches every year and date. Arthropod herbivory was quantified computing the frequency of leaf damage (number of damaged leaves/total), and the leaf area damaged quantified by visual estimation (note that sum of leaf area damaged excluded gallers and borers in this damage category). The damaged area was quantified by visual estimation following the methodologies proposed by Garibaldi et al. (2011). We classified arthropod herbivores and leaf damage into different guilds such as leaf chewers, bud feeders, hole feeders, continuous skeletonizers, sticky skeletonizers, patch skeletonizers, surface abrasion feeders (grouped in to exophagous feeders), and curvilinear miners, linear miners, continuous miners, sap-sucking and wrinkling feeders, and gallers (grouped in to endophagous feeders) (Figs. 1 and 2; protocols and classification were based on McQuillan, 1993; Novotny et al., 2010; Garibaldi et al., 2011). For the analyses, we used three diversity indices: Shannon-Wiener index for diversity, Shannon evenness index for evenness and number of guilds for richness (Magurran, 2004). In addition, planted $N$. obliqua performance was assessed as survival and relative height difference within a growing season, where relative height growth = maximum height of the apical meristem in April - maximum height of the apical meristem in October / maximum height of the apical meristem in October, used as a proxy of plant growth rate (West, 2014). For $N$. obliqua performance we measured all the available planted trees (initially 30 plants for every strip).

In order to characterize the environmental conditions of plots, we measured at each harvesting level: air temperature, relative air humidity (Ibutton DS 1923, U.S.), and PAR (light intensity measured with a ceptometer, Cavadevices Ceptometer, Arg.). Air temperature and relative air humidity were measured throughout the second vegetative growing season, daily and every $30 \mathrm{~min}$, with Dataloggers situated in the middle of one transect at $0.75 \mathrm{~m}$ from the topsoil. PAR was measured at $0.75 \mathrm{~m}$ from the topsoil in December and February, three times in three transects per plot.

\subsection{Statistical analysis}

We analyzed the effects of harvesting intensity on arthropod herbivory guild diversity, evenness and richness, leaf damage frequency (total, exophagous guilds and gallers) and relative plant growth rate (height), using linear mixed-effects models in R (R Core Team 2015), with the lmer function (lme4 package, Bates 2011). For sapling survival, we used generalized linear mixed-effects models, using the glmer function, of the lme4 package (binomial distribution, Bates 2011). These models take into account the hierarchical structure of the data at different levels or classes combining fixed and random effects (Zuur, 2009). The models considered the fixed effects of harvesting intensities (quantitative variable), squared harvesting intensities (to consider nonlinear responses to harvesting) and year (categorical variable), as well as their interactions. In the same model, we evaluated the random effects of plant origins and plots. We used multi-model inference as for the inferential statistical framework (Burnham et al., 2011). We selected the minimum adequate model by the lowest AICc value (corrected form of the Akaike Information Criteria) using the function dredge (package MuMin, Burnham et al., 2011). We calculated the relative importance value for each predictor variable with the importance function in the package MuMin, which sums the 'Akaike weights' over all the models that include the predictor variable. We explored the correlation between herbivory and sapling performance variables using Spearman correlations.

\section{Results}

Intermediate harvesting intensities $(30 \%$ and $50 \%$ of basal area removal) of the mixed forest maximized guild diversity, leaf damage and plant performance of planted $N$. obliqua saplings. The mixed-effects models showed that harvesting intensity and year were important predictors for all response variables (see estimated coefficients of the model and relative importance in Appendices 3 and 4). We found no interaction between harvesting intensity and year for all the guild diversity and leaf damage frequency measures (see estimated coefficients of the model and relative importance in Appendices 3 and 4). Overall, guild diversity and leaf damage frequency were higher during the second year (Figs. 2 and 3). Guild diversity, evenness and richness were maximized both years at intermediate harvesting intensities (Fig. 2). Total leaf damage frequency was also maximized both years at intermediate harvesting rates, achieving $41 \%$ and $53 \%$ for $30 \%$ of harvesting intensity during the first and second year, respectively; and $34 \%$ and $46 \%$ for $50 \%$ of harvesting intensity during the first and second year, respectively (Fig. 3). This pattern was also consistent, during both years, for leaf damage caused by exophagous folivorous (23\% and $31 \%$ at intermediate harvesting intensities for the first and second year, respectively) and gallers (13\% and 19\% at intermediate harvesting intensities for the first and second year, respectively; Fig. 3).

Planted $N$. obliqua saplings had a higher survival rate at intermediate harvesting intensities during both years, and they also grew more at intermediate harvesting intensities during the second year. Overall, more than $50 \%$ of the planted trees survived, while the survival rate at intermediate harvesting intensities was higher than $90 \%$ during the second year (Fig. 4). For plant growth, the model showed a strong interaction between harvesting intensity and year (see estimated coefficients of the model and relative importance in Appendices 3 and 4). Plant growth increased linearly with harvesting intensity during the first year but showed the same nonlinear trend observed for all the other responses variables during the second year (Fig. 4). Maximum plant growth during the first year was around $10 \pm 3 \mathrm{~cm}$ at the highest harvesting intensity but achieved much higher values (around $30 \pm 7 \mathrm{~cm}$ ) during the second year at intermediate harvesting intensities.

In agreement with the reported trends above, guild diversity and leaf damage measures in $N$. obliqua were strongly and positively correlated. In contrast, these measures did not show correlation with plant survival or growth (see correlation parameters in Appendix 5). These results are consistent with the finding that plant survival and growth was higher at intermediate harvesting intensities despite higher leaf damage. Additionally, as regards environmental conditions of plots, air temperature and PAR increased with the increasing harvesting 


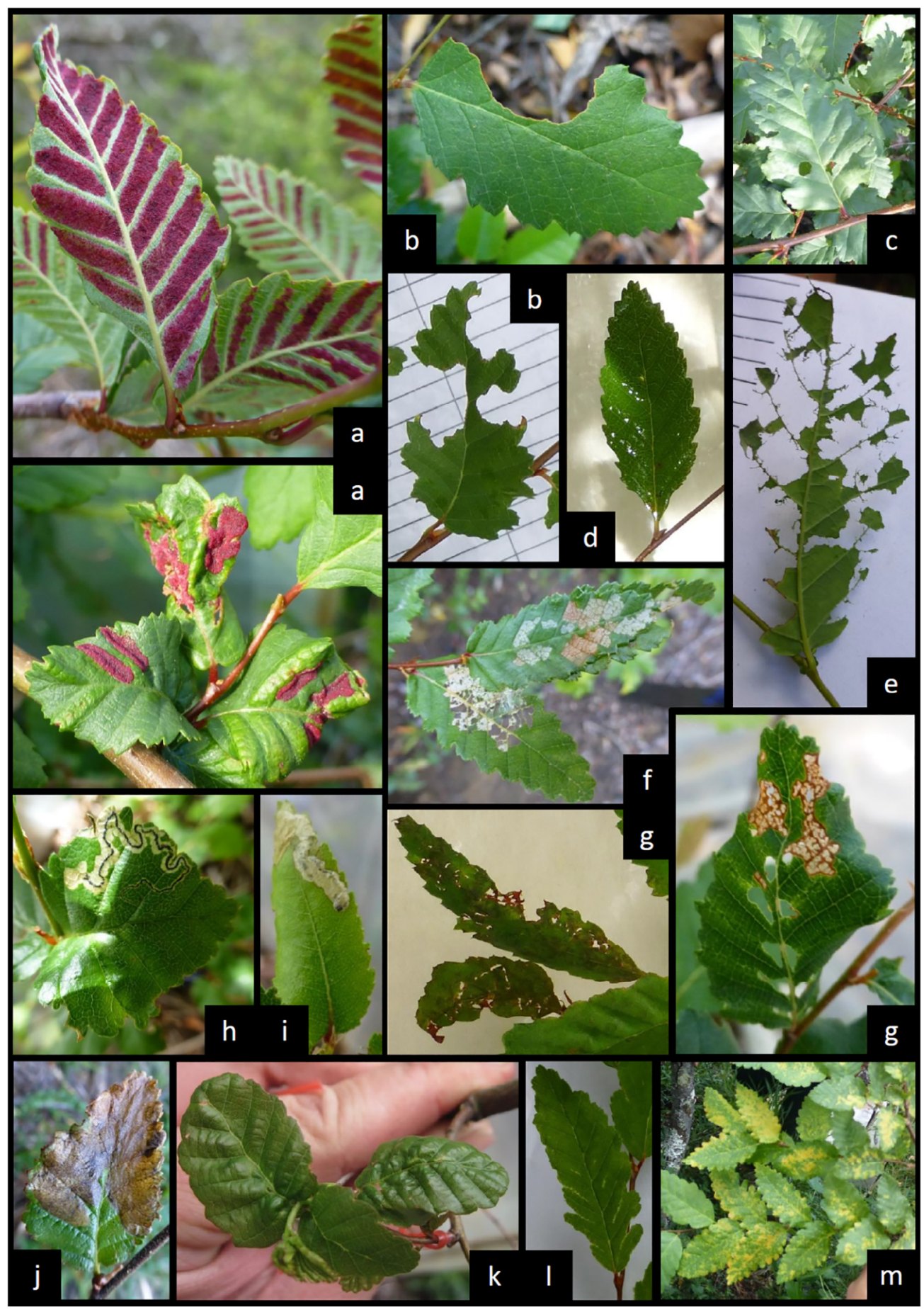

Fig. 1. Herbivorous guilds most commonly seen on Nothofagus obliqua leaves. a. Leaf gallers; b. Leaf chewers; c. Bud feeders; d. Hole feeders; e. Continuous skeletonizers; f. Sticky skeletonizers; g. Patch skeletonizers; h. Curvilinear miners; i. Linear miners; j. Continuous miners; k. Sap-sucking and wrinkling feeders; 1. Surface abrasion feeders; m. Damage type non-identified (possibly sap-sucking feeders damage).

intensities, whereas relative air humidity decreased with increasing harvesting intensities (Appendix 6).

\section{Discussion}

Sustainable forest management needs to conserve and enhance biodiversity while increasing productivity. Although achieving both could be a challenge, it should not always be impossible. We found that intermediate harvesting intensities of natural mixed forest in northern Patagonia did enhance not only the success of native tree plantation practices but also achieved both purposes: sustaining the highest arthropod diversity (e.g. largest herbivory consumption rates and damage types) while reaching maximum plant productivity. These responses were consistent across contrasting feeding guilds, using different diversity indices, and during the two study years. Canopy opening generated by harvesting modified key microclimatic factors such as temperature, relative humidity and the amount of light, all of which improved native plant and animal performance.

Intermediate harvesting intensities promoted the largest diversity, evenness and richness of arthropod herbivore guilds on planted native 

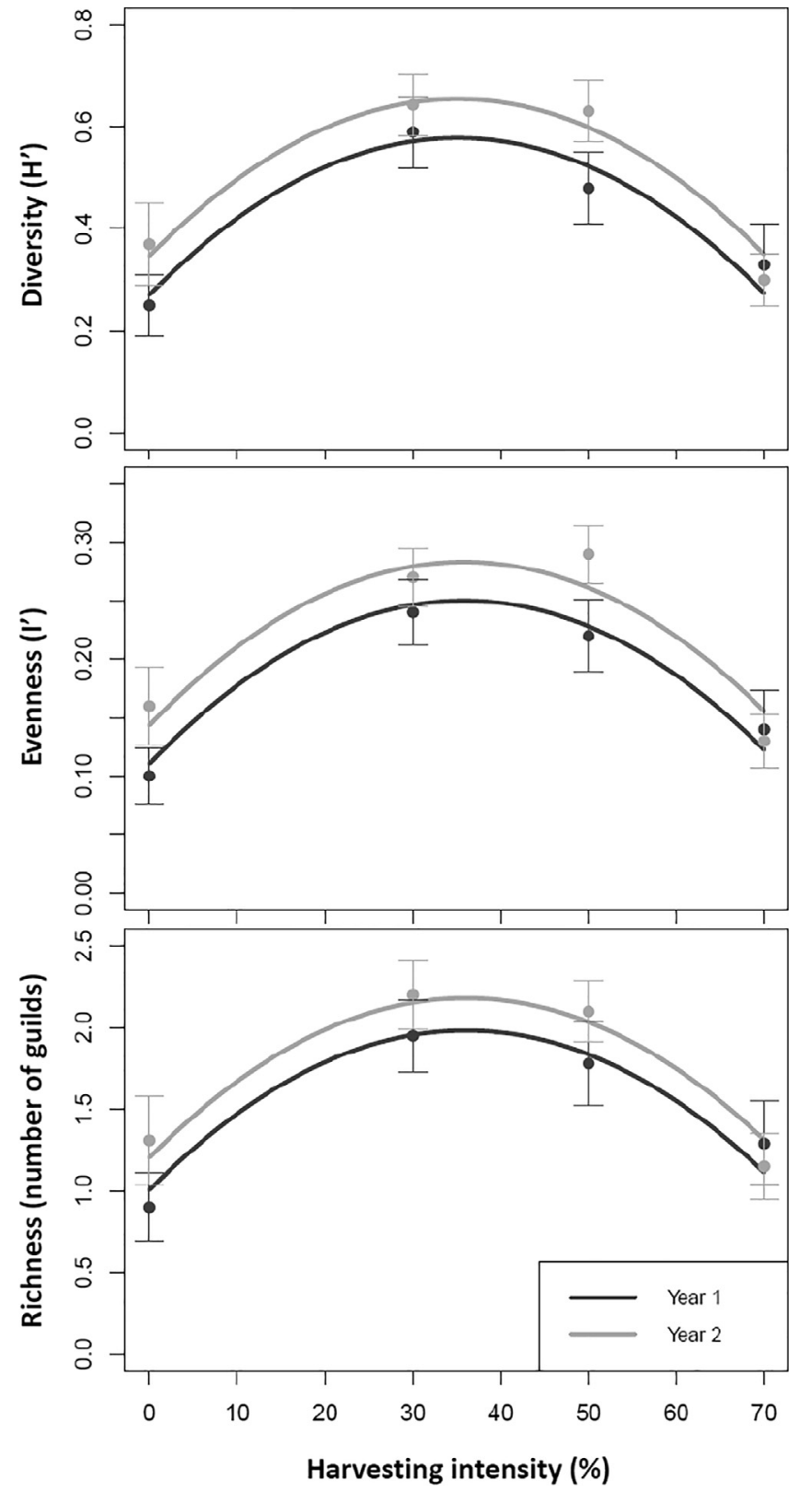

Fig. 2. Response of diversity, evenness and richness of feeding guilds to harvesting intensity. Each point is the average value of a plot (and SE), and curves are the predicted values from mixed-effects models.

tree saplings, supporting the intermediate disturbance hypothesis (Schowalter, 2012; Liebhold et al., 2018; Muiruri et al., 2019). Specifically, intermediate harvesting intensities could generate optimal temperature, humidity and light conditions for most of the forestdwelling arthropod herbivores (Gossner et al., 2014; Soler et al., 2016) as well as host greater plant quality and density (Coulin et al., 2019). In Patagonia, only a few studies have evaluated the effects of forest management on insect diversity and found similar results for different insect taxa than those studied here. In particular a meta-analysis for southern Patagonian forests found that stands under variable retention (including aggregate and dispersed retention) management supported higher diversity of insects than unmanaged forests, where the proportional amount of old-growth insect loss after management was 35\% in aggregate, $55 \%$ in dispersed retention, and $60-75 \%$ in clear-cuts (Lencinas et al., 2014; Soler et al., 2016). In contrast, a meta-analysis for temperate forests of Europe for the direct use of forest resources including thinning, tree retention, and planting found that species

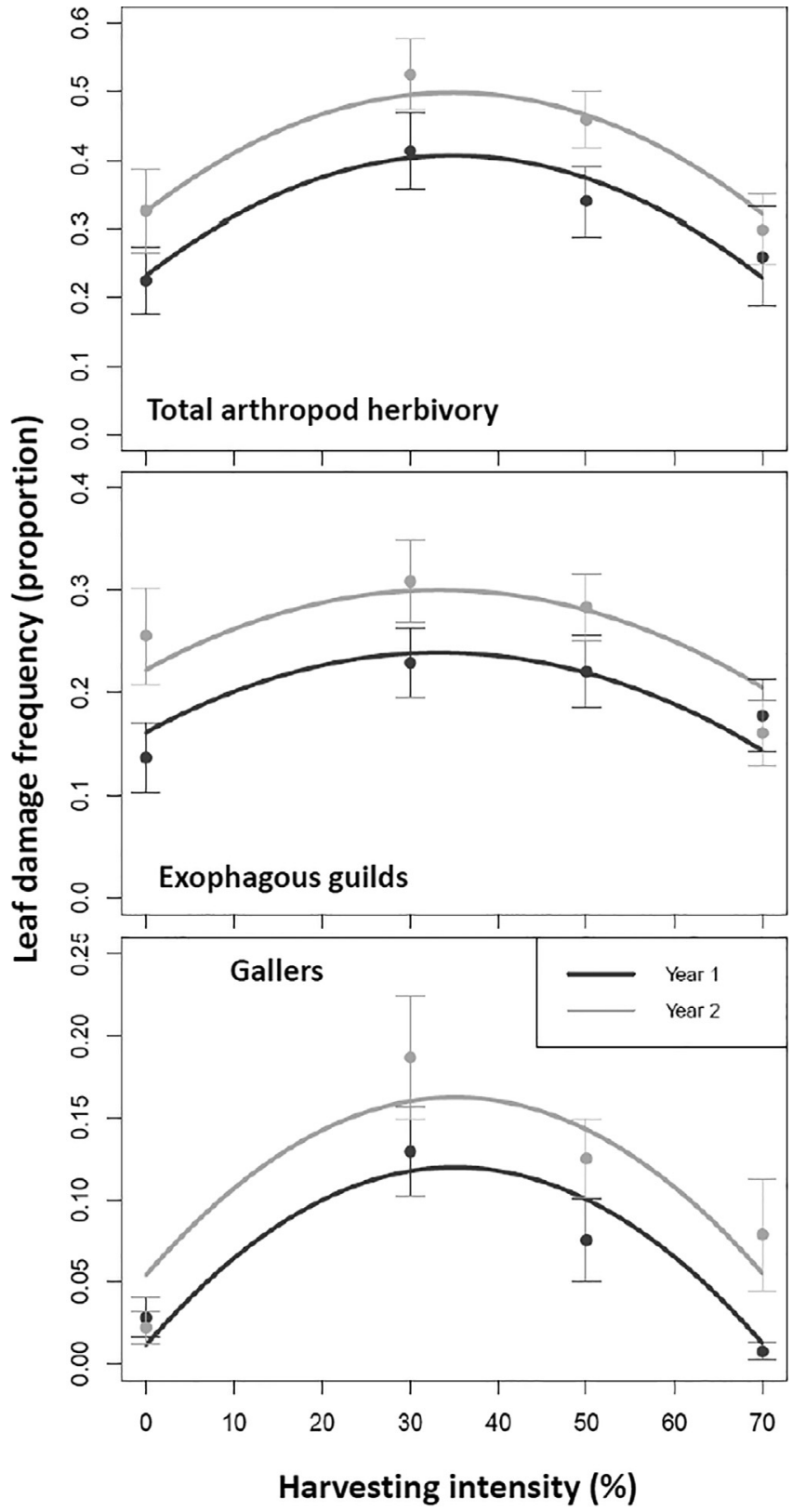

Fig. 3. Response of damage frequency by all, exophagous or gallers feeding guilds to harvesting intensity. Each point is the average value of a plot (and SE), and curves are the predicted values from mixed-effects models.

richness was slightly higher in unmanaged than in managed forests (Paillet et al., 2010). Similarly, Savilaakso et al. (2009) found for tropical forests of Uganda that arthropod herbivory, larval density, and species richness were significantly lower in the logged forest (with a basal area reduction of $30 \%$ and $50 \%$ after 40 years of regeneration) than in a natural forest. Additionally, different types of arthropod herbivore damage respond in a complex way under forest management regimes in the temperate forests of Germany (unmanaged, uneven-aged managed, even-aged managed), and there was no significant difference in species richness and arthropod herbivore abundance (Gossner et al. 2014). Despite potential regional differences driving the opposite trends, it is important to note that the above-cited studies have focused on insect species richness (herbivores and other groups) from remnant vegetation after harvesting and following larger time windows from management practice. Hence, further long term surveys in our study site are required for the focal planted trees as well as assessments of 

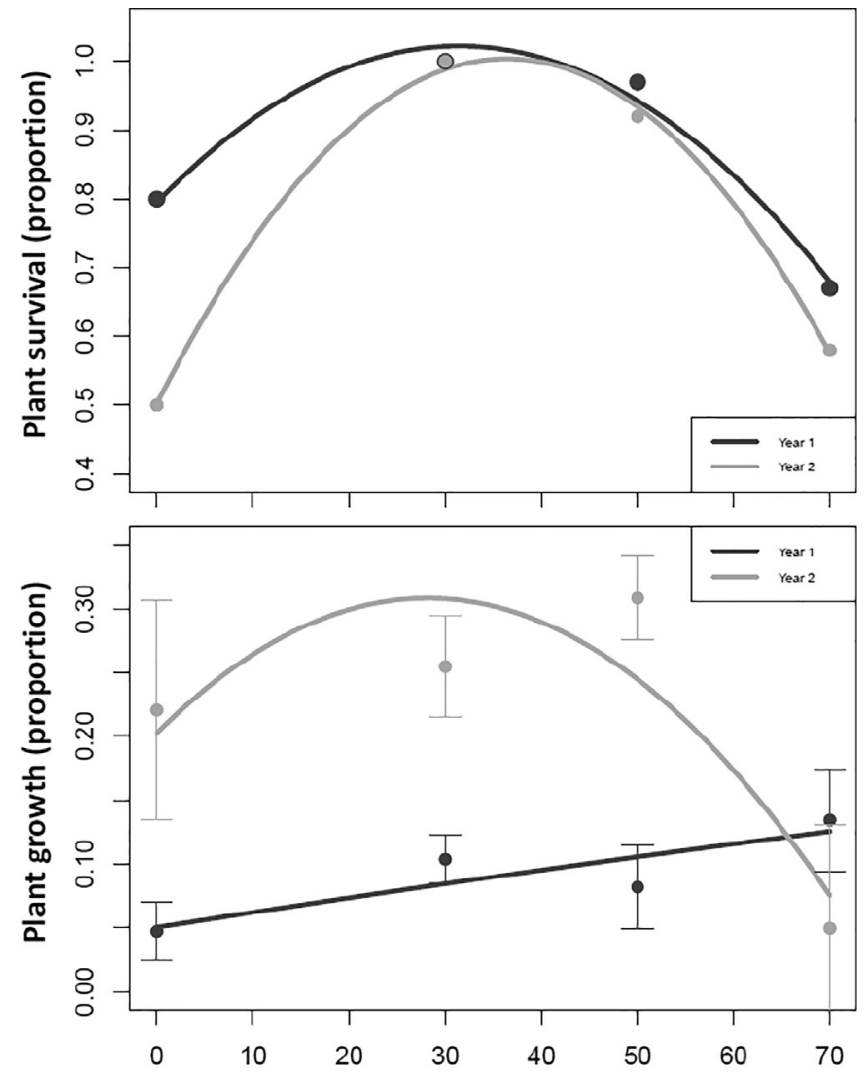

Harvesting intensity (\%)

Fig. 4. Response of plant survival and growth to harvesting intensity. Each point is the overall survival or average growth value of a plot (and SE), and curves are the predicted values from mixed-effects models.

diversity indices in the remaining woody species of the native mixed forest.

Leaf damage was also higher at intermediate harvesting intensities during both years. Although, contrasting hypotheses explain changes in the consumption rate of different arthropod herbivore guilds (Vidal \& Murphy, 2018), in our study generalist (i.e. exophagous) and specialist (e.g. gallers) arthropod guilds responded in the same way. Moreover, given a similar response to harvesting intensity between arthropod herbivory and plant survival rates, and the different behaviour of plant growth, this scenario would not support the plant vigour hypothesis. In addition, it does not support the plant diversity hypothesis either, since at intermediate harvesting intensities, no greater plant diversity was recorded (Coulin et al., 2019). Instead, our results might reflect a higher resource concentration of the study species because of enhanced tree survival. The higher probability of encountering the focal plants could be an example of positive effects of connectivity on the arthropod herbivory rates on $N$. obliqua (Maguire et al., 2015). Additionally, planted trees are more challenging to find without harvesting; there is less food available due to the absence of regeneration of herbs and shrubs, as well as lower average temperature due to the shadow (Gossner et al., 2014). At the other end, with very high harvesting intensities, leaf palatability might be lower (this needs to be confirmed in future studies), and there are less resource concentration and vegetation continuity (Mazía et al., 2012; Hambäck et al., 2014).

Our study shows a strong positive correlation between arthropod herbivore guild diversity and arthropod herbivory rates for N. obliqua. We found no studies analyzing the relation between herbivore guild diversity and herbivore rates, but there are some examples of positive relations between herbivore diversity and abundance (Neves et al., 2010, 2014; Kuchenbecker \& Fagundes, 2018). Guild diversity could enhance herbivore abundance (Lewinsohn et al., 2005) potentially explaining greater leaf consumption rates (Siemann et al., 1996; Novotny et al., 2010, 2012; Pinheiro et al., 2016; Muiruri et al., 2019), because of niche complementarity (Gable et al., 2012; Valencia-Cuevas and Tovar-Sánchez, 2015). Finally, diversity indices and herbivory rates were higher during the second year, as well as the regional temperature (SMN, 2019), consistent with the idea that temperature is suboptimal for arthropods in temperate environments such as Patagonia (Cornelissen, 2011; Garibaldi et al., 2011). Therefore, management techniques that aid to increase understory temperature slightly may benefit herbivore arthropod diversity at this latitudes.

The planted trees also showed higher survival rates at intermediate harvesting intensities. However, tree saplings growth increased linearly with harvesting intensity during the first year, and only during the second year, the plants grew more at intermediate harvesting intensities. In agreement with previous studies showing that deciduous Nothofagus (e.g. $N$ pumilio, $N$. obliqua, $N$. alpina) are established more successfully under moderate conditions of light and soil moisture (Varela et al., 2012, Donoso Zegers, 2013), we believe in our system a trade-off might be taking place between light deficiency (low harvesting intensities) and water stress (high harvesting intensities). For $N$. obliqua, Varela et al., (2012) reported survival rates around $70 \%$ in similar areas, and Donoso Zegers (2013) has mention several survival rates being the highest one ( $90 \%$ survival) is under $35 \%$ of vegetation cover. However, the degree of adequate cover might not be constant as it was shown to depend on water availability, varying from around $40 \%$ of cover in humid sites to $80 \%$ in dry sites for $N$. obliqua (Azpilicueta et al., 2010).

Although it has been recorded that $N$. obliqua establishment is negatively affected by defoliation caused by arthropods (Donoso Zegers, 2013), we found that when their leaves are consumed by a more diverse arthropod community and are more damaged, plants have higher survival rates and grow better. To further confirm this result, future studies should consider long-term monitoring (e.g., plant palatability may change along with plant ontogeny) and a wide range of environmental conditions. Direct effects of defoliation, such as decreased photosynthetic capacity, disrupt the process of translocation and transpiration reducing plant growth (Bauerle et al., 1997) and potential plant survival (Piper et al., 2015). In contrast, in our study system, we believe that micro-environmental factors could be more important than arthropod herbivory. Regardless of the mechanism, it is interesting to note that $N$. obliqua showed high survival rate, despite it was planted south of its natural distribution. Because of the ongoing climate change, this species may hence disperse to southern sites (Lenoir \& Svenning, 2015). Despite the strong and consistent pattern for overall plants and herbivores both years, it will be important to analyze in future studies if the patterns that we found are consistent at larger spatial scales and for a higher number of plots, given that our results could be highly influenced for the particular behavior of the insects at our experimental site.

\section{Conclusions}

In the context of sustainable forest management, we found no evidence of trade-offs between biodiversity and tree performance; instead, we showed that those could be enhanced together. Secondly, we found that for planted N. obliqua saplings arthropod guild diversity, associated arthropod herbivory, and tree growth and survival showed non-linear responses to management intensity, being all highest at intermediate harvesting intensities. The intermediate harvesting intensity in Patagonian mixed forests can supply sufficient firewood (Goldenberg et al. 2018) while providing ideal abiotic and biotic conditions for native tree plantations. These trends suggest that $N$. obliqua can have excellent forestry potential in the region while being a habitat for insect diversity conservation (Aidoo et al., 2016). Thirdly, there was a strong positive correlation between guild diversity and leaf damage, which shows the interdependency between them on planted saplings in mixed 
forest. This work also composes an approach to understanding the responses of herbivorous arthropods in a new productive context, necessary to improve the ecological knowledge for integrated pest management (Maguire et al., 2015, Klapwijk et al., 2016). Maximizing production and diversity is still a challenge for sustainable management, but certain intermediate levels of management intensity can provide positive outcomes between herbivore diversity and tree survival. It is that this type of "win-win" scenario could also be achieved in other harvested forests where planted trees are native or phylogenetically related to local ones.

\section{Authors' contributions}

LG and MN conceived the idea and designed the study. MN collected the data. MN, TK and LG analyzed and interpreted the data and led the writing of the manuscript with substantial input from all co-authors. All authors gave final approval for publication.

\section{Declaration of Competing Interest}

The authors declare that they have no known competing financial interests or personal relationships that could have appeared to influence the work reported in this paper.

\section{Acknowledgements}

We thank C. Quintero, F. Tiribelli, M. Goldenberg, N. Pérez Méndez, G. Andersson, A. González, V. Piazza, A. Girotto and G. Longo, who made valuable comments to preliminary versions of the manuscript. Also M.J. Aguilar, S. Varela, K. Castro, A. Iglesias and A. Ñanco who assisted in the field. This work was supported by the Agencia Nacional de Promoción Científica y Tecnológica of Argentina (grants PICT 20131079 and PICT 2016-0305).

\section{Appendix A. Supplementary data}

Supplementary data to this article can be found online at https:// doi.org/10.1016/j.foreco.2019.117738.

\section{References}

Aidoo, O.F., Kyerematen, R., Afreh-Nuamah, K., 2016. Abundance and Diversity of Insects Associated with Citrus Orchards in Two Different Agroecological Zones of Ghana. Am. J. Exp. Agr. 13 (2), 1-18.

Azpilicueta, M. M., Varela, S., et al. (2010). Manual de viverización, cultivo y plantación de Roble Pellín en el norte de la región Andino Patagónica. Instituto Nacional de Tecnología Agropecuaria EEA Bariloche. 72 pp. ISBN 978-987-1623-87-7.

Azpilicueta, M.M., Marchelli, P., et al. (2016). Zonas genéticas de raulí y roble pellín en Argentina : herramientas para la conservación y el manejo de la diversidad genética. 1a ed. Ediciones INTA. 50 p.p. ISBN 978-987-521-765-2.

Barbero, F., Sabatier, Y., et al. (2011). Áreas potenciales de cultivo de raulí y roble pellín en la provincia de Río Negro. 1a ed. Ediciones INTA. 60 p.p. ISBN 978-987-679004-8.

Bauerle, P., Rutherford, P., Lanfranco, D., 1997. Defoliadores de roble (Nothofagus obliqua), rauli (N. alpina), coigue (N. dombeyi) y lenga (N. pumilio). Bosque 18 (2), 97-107.

Bauhus, J., Meer, P. van der., \& Kanninen, M. (2010). Ecosystem goods and services from plantation forests, 1st ed. Earthscan, London, 254 p. ISBN: 978-1-84971-168-5.

Bates, D., 2011. Mixed models in R using the lme4 package Part 6: Nonlinear mixed models. Statistics 1-9.

Bravo-Oviedo, A., Pretzsch, H., del Río, M. (2018). Dynamics, Silviculture and Management of Mixed Forests. 420 p.p. 1st Ed. Springer International Publishing. ISBN: 978-3-319-91952-2.

Burnham, K.P., Anderson, D.R., Huyvaert, K.P., 2011. AIC model selection and multimodel inference in behavioral ecology: Some background, observations, and comparisons. Behav. Ecol. Sociobiol. 65, 23-35.

Castagneyrol, B., Giffard, B., Jactel, H., 2013. Plant apparency, an overlooked driver of associational resistance to insect herbivory. J. Ecol. 101, 418-429.

Chaudhary, A., Burivalova, Z., Hellweg, S., 2016. Impact of Forest Management on Species Richness: Global Meta-Analysis and Economic Trade-Offs. Sci. Rep. 6.

Cornelissen, T., 2011. Climate change and its effects on terrestrial insects and herbivory patterns. Neotropical Entomology 40, 155-163.

Cornelissen, T., Wilson Fernandes, G., Vasconcellos-Neto, J., 2008. Size does matter:
Variation in herbivory between and within plants and the plant vigor hypothesis. Oikos 117, 1121-1130.

Coulin, C., Aizen, M., Garibaldi, L.A., 2019. Contrasting responses of plants and pollinators to woodland disturbance. Austral Ecol. https://doi.org/10.1111/aec.12771.

Donoso Zegers, C., 2013. Las especies arbóreas de los bosques templados de Chile y Argentina: autoecología. Cuneo, Valdivia.

Donoso \& A. Promis (Eds.). (2015). Silvicultura en los bosques nativos: avances en la investigación en Chile, Argentina y Nueva Zelanda (pp. 109-151). Valdivia, Chile. Editorial Marisa Cuneo. ISBN: 978-956-7173-32-7.

FAO. (2016). State of the World's Forests 2016. Forests and agriculture: land-use challenges and opportunities. Rome. ISBN 978-92-5-109208-8.

Gable, J.T., Crowder, D.W., Snyder, W.E., 2012. Niche engineering reveals complementary resource use. Ecology 93, 1994-2000.

Garibaldi, L.A., Kitzberger, T., Chaneton, E.J., 2011. Environmental and genetic control of insect abundance and herbivory along a forest elevational gradient. Oecologia 167, 117-129.

Goldenberg, M.G., Gowda, J.H., Garibaldi, L.A., 2018. Efecto de la tasa de descuento sobre la priorización de alternativas de manejo del matorral Norpatagónico argentino. Bosque (Valdivia) 39, 217-226.

Gönc, R., Casaux, R.J., Sulkin-Dolhatz, D., 2015. Effects of disturbances generated by different management strategies on the vegetation strata of Nothofagus antarctica forests of Chubut, Argentina. Ecología Austral 25, 231-241.

Gong, B., Zhang, G., 2014. Interactions between plants and herbivores: A review of plant defense. Acta Ecologica Sinica 34, 325-336.

Gossner, M.M., Pašalić, E., Weisser, W.W., 2014. Differential responses of herbivores and herbivory to management in temperate European beech. PLoS ONE 9 (8), e104876.

Hambäck, P.A., Inouye, B.D., Underwood, N., 2014. Effects of plant neighborhoods on plant-herbivore interactions: Resource dilution and associational effects. Ecology 95, 1370-1383.

Klapwijk, M.J., Bylund, H., Björkman, C., 2016. Forest management and natural biocontrol of insect pests. Forestry 89, 253-262.

Kuchenbecker, J., Fagundes, M., 2018. Diversity of insects associated with two common plants in the Brazilian Cerrado: Responses of two guilds of herbivores to bottom-up and top-down forces. Eur. J. Entomol. 115, 354-363.

Lencinas, M.V., Martínez Pastur, G., Cellini, J.M., 2014. Decreasing negative impacts of harvesting over insect communities using variable retention in southern Patagonian forests. J. Insect Conserv. 18, 479-495.

Lenoir, J., Svenning, J.C., 2015. Climate-related range shifts - a global multidimensional synthesis and new research directions. Ecography 38, 15-28.

Lewinsohn, T.M., Novotny, V., Basset, Y., 2005. Insects on Plants: Diversity of Herbivore Assemblages Revisited. An. Rev, of Ecology. Evolution, and Systematics 36, 597-620.

Liebhold, A.M., Yamanaka, T., Pyšek, P., 2018. Plant diversity drives global patterns of insect invasions. Sci. Rep. 8 (1), 12095. https://doi.org/10.1038/s41598-01830605-4.

Liu, C.L.C., Kuchma, O., Krutovsky, K.V., 2018. Mixed-species versus monocultures in plantation forestry: Development, benefits, ecosystem services and perspectives for the future. Gl. Ec. and Cons. 15, e00419. https://doi.org/10.1016/j.gecco.2018. e00419.

Magurran, A. (2004). Measuring Biological Diversity. p. 248. Blackwell Science Ltd. ISBN: 978-0-632-05633-9.

Mazía, N., Chaneton, E.J., Kitzberger, T., 2012. Seasonal patterns of herbivory, leaf traits and productivity consumption in dry and wet Patagonian forests. Ecol. Ent. 37, 193-203.

McQuillan, P.B., 1993. Nothofagus (Fagaceae) and its invertebrate fauna-an overview and preliminary synthesis. Biol. J. Linnean Soc. 49, 317-354.

Maguire, D.Y., James, P.M., Bennett, E.M., 2015. Landscape connectivity and insect herbivory: A framework for understanding tradeoffs among ecosystem services. Gl. Ec. and Cons, 4, 73-84.

Muiruri, E.W., Barantal, S., Koricheva, J., 2019. Forest diversity effects on insect herbivores: do leaf traits matter? New Phytol. 221, 2250-2260.

Neves, F.S., Araújo, L.S., Quesada, M., 2010. Canopy herbivory and insect herbivore diversity in a dry forest-savanna transition in Brazil. Biotropica 42, 112-118.

Neves, F.S., Silva, J.O., Fernandes, G.W., 2014. Insect Herbivores and Leaf Damage along Successional and Vertical Gradients in a Tropical Dry Forest. Biotropica 46, 14-24.

Novotny, V., Miller, S.E., Weiblen, G.D., 2010. Guild-specific patterns of species richness and host specialization in plant-herbivore food webs from a tropical forest. J. Anim. Ecol. 79, 1193-1203.

Novotny, V., Miller, S.E., Weiblen, G.D., 2012. Insects on Plants: Explaining the Paradox of Low Diversity within Specialist Herbivore Guilds. The American Naturalist 179, 351-362.

Pafundi, L., Urretavizcaya, M.F., Defossé, G.E., 2016. Micro-environmental changes induced by shape and size of forest openings: Effects on Austrocedrus chilensis and Nothofagus dombeyi seedlings performance in a Pinus contorta plantation of Patagonia. Argentina. Forest Systems 25 (3).

Paillet, Y., Bergès, L., Virtanen, R., 2010. Biodiversity differences between managed and unmanaged forests: Meta-analysis of species richness in Europe. Cons. Biol. 24 (1), $101-112$.

Pinheiro, E.R.S., Iannuzzi, R., Duarte, L.D.S., 2016. Insect herbivory fluctuations through geological time. Ecology 97, 2501-2510.

Piper, F.I., Gundale, M.J., Fajardo, A., 2015. Extreme defoliation reduces tree growth but not C and N storage in a winter-deciduous species. Ann. Bot. 115, 1093-1103.

Reque, J., 2007. Caracterización silvícola de ñirantales del norte de la Patagonia para la gestión forestal sostenible. Bosque (Valdivia) 28, 33-45.

Rusch, V., López, D.R., Peri, P., 2017. Modelo de estados y transiciones de los ñirantales del NO de la Patagonia como herramienta para el uso silvopastoril sustentable. Ecologia Austral 27, 266-278. 
Savilaakso, S., Koivisto, J., Roininen, H., 2009. Long lasting impact of forest harvesting on the diversity of herbivorous insects. Biodivers. Conserv. 18, 3931-3948.

Schowalter, T.D., 2012. Insect responses to major landscape-level disturbance. Annu. Rev. Entomol. 57, 1-20.

Servicio Meteorológico Nacional https://www.smn.gob.ar. Caracterización estadística de largo plazo. Vigilancia del clima. Monitoreo de temperatura y precipitación 20132015. Patagonia norte 2019 Argentina.

Siemann, E., Tilman, D., Haarstad, J., 1996. Insect species diversity, abundance and body size relationships. Nature 380, 704-706.

Silva, J.O., Espírito-Santo, M.M., Fernandes, G.W., 2016. Galling Insect Species Richness and Leaf Herbivory in an Abrupt Transition between Cerrado and Tropical Dry Forest. Annals of the Ent. Soc. of Am. 109, 705-712.

Soler, R.M., Schindler, S., Martínez Pastur, G., 2016. Why biodiversity increases after variable retention harvesting: A meta-analysis for southern Patagonian forests. For. Ec. and Man. 369, 161-169.

Soto, D.P., Donoso, P.J., Puettmann, K.J., 2015. Light availability and soil compaction influence the growth of underplanted Nothofagus following partial shelterwood harvest and soil scarification. Can. J. For. Res. 45, 998-1005.

Speziale, K.L., Ezcurra, C., 2011. Patterns of alien plant invasions in northwestern Patagonia, Argentina. J. Arid Environ. 75, 890-897.

Stam, J.M., Kroes, A., Dicke, M., 2014. Plant Interactions with Multiple Insect Herbivores:
From Community to Genes. Annu. Rev. Plant Biol. 65, 689-713.

Turcotte, M.M., Thomsen, C.J.M., Johnson, M.T.J., 2014. Percentage leaf herbivory across vascular plants species. Ecology 95, 788.

Underwood, N., Inouye, B.D., Hambäck, P.A., 2014. A Conceptual Framework for Associational Effects: When Do Neighbors Matter and How Would We Know? Q. Rev. Biol. 89, 1-19.

Valencia-Cuevas, L., Tovar-Sánchez, E., 2015. Oak Canopy arthropod communities: Which factors shape its structure? Rev. Chil. de Hist. Nat. 88, 15.

Varela, S.A., Fernández, M.E., Schlichter, T.M., 2012. Physiological and morphological short-term responses to light and temperature in two Nothofagus species of Patagonia. South America. Photosynthetica 50 (4), 557-569.

Veblen, T.T., Kitzberger, T., Lara, A., 2006. Disturbance and forest dynamics along a transect from Andean rain forest to Patagonian shrubland. J. Veg. Sci. 3, 507-520.

Vidal, M.C., Murphy, S.M., 2018. Bottom-up vs. top-down effects on terrestrial insect herbivores: a meta-analysis. Ecol. Lett. 21, 138-150.

West, P.W., 2014. Growing plantation forests. Growing Plantation Forests. Springer International Publishing, Australia.

White, T.C.R., 2009. Plant vigour versus plant stress: A false dichotomy. Oikos 118, $807-808$.

Zuur, A.F., Ieno, E.N.,... Smith, G.M. (2009). Mixed Effects Models and Extensions in Ecology with R. Springer. 574p. ISBN 978-0-387-87457-9. 